\title{
CZY MOŻLIWE BYŁO ODKUPIENIE CZŁOWIEKA BEZ ŚMIERCI KRZYŻOWEJ JEZUSA?
}

Odpowiedź na tytułowe pytanie nie pojawia się często, a nawet jeśli już, to zwykle dzieje się to niejako na marginesie, jako zaledwie sygnalizacja czy propozycja do opracowania. Można zaryzykować stwierdzenie, że odczuwa się swoisty dystans do prowadzenia tego typu badań. Nie ma w tym nic dziwnego. Pierwotnym przedmiotem zainteresowania i badań jest przecież to, co się dokonało, realność, konkret, rzeczywistość, a nie to, co ewentualnie mogłoby się dokonać. Owszem, badanie czegoś w odwołaniu się do zasady niesprzeczności może być interesujące, ale nie jest tak ważne, jak to, co faktycznie się dokonało; fakty dokonane zawsze mają pierwszeństwo przed faktami możliwymi. Wydaje się jednak, że podjęty tutaj temat jest ważny, zwłaszcza dla antropologii czy teologii życia wewnętrznego. Te właśnie powody stanowiły rację dostateczną, ażeby tę problematykę raz jeszcze poddać analizom.

Ażeby zaprezentowane analizy ukazać w jak najbardziej przejrzystej formie, przedstawimy najpierw argumenty za tym, że droga do odkupienia człowieka mogła wieść jedynie przez krzyż, następnie przedstawimy argumenty przeciwne, wskażemy też na pewne trudności i na koniec wyciągniemy wnioski.

\section{Odkupienie człowieka nie mogło dokonać się inaczej, jak tylko przez śmierć Jezusa na krzyżu}

Teksty biblijne zawierają w sobie tak jasne i jednoznaczne proroctwa dotyczące męki i śmierci Mesjasza, że wydaje się, iż stawianie pytań o możliwość odkupienia na innej drodze jest pozbawione sensu. Za tak zdecydowaną odpowiedzią przemawiają zarówno zapowiedzi 
zawarte w Starym Testamencie, jak również ich wyjaśnienia pochodzące z kart Nowego Testamentu. Wystarczy przecież wczytać się w Psalm 22 czy też w 53 rozdział z Księgi Izajasza, aby napotkać zdecydowane i jednoznaczne zapowiedzi tego, co miało wydarzyć się z cierpiącym Sługą Pana dokonującym dzieła odkupienia człowieka. Tekstów tych nie będziemy tutaj przytaczać, gdyż są one powszechnie znane i łatwe do odszukania w celu przypomnienia. Uczynimy wyjątek dla jednej wypowiedzi, pochodzącej już z Nowego Testamentu, z drugiej mowy św. Piotra, który, odwołując się do świętych Pism Starego Testamentu, wyjaśnia konieczność tego wszystkiego, co się w życiu Jezusa dokonało. Apostoł mowę tę wygłosił po uzdrowieniu chromego przy bramie zwanej Piękną. Wyrzucał w niej Izraelitom zabicie „Dawcy Życia” (Dz 3, 15). Jednocześnie wlewał w nich nadzieję, mówiąc: „Lecz teraz wiem, bracia, że działaliście w nieświadomości, tak samo jak zwierzchnicy wasi. A Bóg w ten sposób spełnił to, co zapowiedział przez usta wszystkich proroków, że Jego Mesjasz będzie c i e r p i a 1" (Dz 3, 17-18; tu i dalej podkreślenia - R.K.W.).

Jednoznacznie też brzmią słowa homilii św. Andrzeja z Krety, które Kościół czyta w święto Podwyższenia Krzyża świętego. Święty biskup głosił, że ,gdyby nie było krzyża, Chrystus nie zostałby ukrzyżowany. Gdyby nie było krzyża, Życie nie zostałoby przybite gwoździami do drzewa. Gdyby nie było przybite gwoździami, z boku nie wypłynęłaby krew i woda dla oczyszczenia świata, dokument grzechu nie zostałby zniszczony, nie otrzymalibyśmy wolności, nie radowalibyśmy się drzewem życia, raj nie zostałby otwarty. Jeśliby nie było krzyża, śmierć nie byłaby zwyciężona, piekło nie zostałoby pozbawione swej mocy". ${ }^{1}$ Takie samo stanowisko prezentuje św. Tomasz z Akwinu. W rozprawie o „Wierzę w Boga” stawia interesujące nas pytanie: „Czy konieczna była dla nas Męka Syna Bożego?” I zdecydowanie na nie odpowiada: „Bezwzględnie i podwójnie konieczna: konieczna jako lekarstwo przeciw grzechom oraz konieczna

1 Św. A ndrzej z K ret y, Oratio 10 in Exaltatione Sancte Crucis, w: Liturgia Godzin, t. IV, Pallotinum 1988, s. 1164. 
jako przykład do naśladowania. Męka Chrystusa - wyjaśnia dalej Doktor Anielski - jest nade wszystko lekarstwem, albowiem dzięki niej znajdujemy ratunek przeciw wszelkiemu złu, któremu poddani jesteśmy z powodu naszych grzechów. Wielki jest również pożytek Męki jako przykładu. Albowiem zdolna jest dogłębnie przemienić nasze życie". ${ }^{2}$

Na ten temat wypowiedział się również kard. Joseph Ratzinger papież Benedykt XVI. Swój punkt widzenia przedstawił przy okazji badań dotyczących ustanowienia Eucharystii oraz ekspiacyjnego charakteru męki i śmierci Pana Jezusa. Nie będziemy zajmować się głównym wątkiem prowadzonych przez niego analiz (byłoby to zasadniczo ich powtórzenie), a naszą uwagę skoncentrujemy właśnie na tym, co dla niego stanowiło zaledwie tło głównych dociekań.

W dialogu prowadzonym z Rudolfem Peschem oraz Peterem Fiedlerem papież, przywołując opinie pierwszego z wyżej wymienionych teologów, podkreślił, że w ich interpretacji misja św. Jana Chrzciciela, poprzednika Jezusa, polegała najpierw na wzywaniu ludu do nawrócenia. Sam zaś Jezus swoją publiczną działalność (tzw. okres galilejski) również rozpoczął jako „posłaniec radości”, zwiastujący bliskość królestwa Bożego, wolę bezwarunkowego przebaczenia oraz panowanie Bożej dobroci i miłosierdzia. ${ }^{3}$ Misja Jezusa byłaby zatem kontynuacją i dopełnieniem nauczania św. Jana Chrzciciela, przez co całość orędzia byłaby pewną spoistą całością. (Chociaż papież w tym miejscu nie kieruje się ku tej wypowiedzi, to jednak warto ją tutaj przywołać, a jest nią wyznanie św. Jana Chrzciciela, który o Jezusie mówił: „Oto Baranek Boży, który gładzi grzech świata” /J 1, 29/, przez co wskazał na Jezusa, jako Ofiarę złożoną za zbawienie świata). Papież kontynuuje swoje analizy, koncentrując się na stwierdzeniach Pescha, któremu wtóruje Peter Fiedler, utrzymujący, że Jezus głosił bezwarunkowo przebaczającego Ojca, bez powiązania

2 Św. Tomasz z A kw in u, Rozprawa 6 o,,Wierzę w Boga”, w: tamże, t. III, Pallotinum 1987, s. 1079.

3 J. R a t z i nge r/ B e n e d y k t XVI, Jezus z Nazaretu, cz. 2, thum. W. S z y m o n a, Kielce 2011, s. 131. 
Jego miłości z ekspiacją. Ten ostatni wątek, ekspiacji, pojawił się twierdzą owi teologowie - dopiero później w tzw. okresie jerozolimskim. Dalej, papież, pomijając Fiedlera, ale dodając Gerharda Lohfinka oraz Ulricha Wilckensa, pisze, że przywołani teologowie zaprezentowany powyżej schemat uznają nie tylko za niesprzeczny, ale za sensowny, czyli poprawny. ${ }^{4}$ Jak pisze papież, owi teologowie „twierdzą, że Jezus przedstawił na początku propozycję orędzia o Królestwie Bożym i bezwarunkowego przebaczenia, musiał jednak przyjąć do wiadomości porażkę tej propozycji, i swoje posłannictwo utożsamił wtedy z misją Sługi Jahwe. Zrozumiał, że po odrzuceniu tej Jego propozycji, pozostawała jedynie droga zastępczej ekspiacji: że musi wziąć na siebie wiszące nad Izraelem nieszczęście, by w ten sposób zapewnić zbawienie wielu". 5

Papież jakby z głębokim zadumaniem pyta: „Co mamy na to powiedzieć?" Tok zrozumień przedstawiający procesualny rozwój dziejów zbawienia, wskazujący na ,wejście na nową drogę miłości po porażce pierwszej propozycji, jest z pewnością zupełnie możliwy i zgodny z całą strukturą biblijnego obrazu Boga i historii zbawienia". ${ }^{6}$ Drogi historii zbawienia ukazane w Starym Testamencie świadczą właśnie - jak to nazywa Benedykt XVI - o pewnej ,«elastyczności» Boga, który oczekuje dobrowolnej decyzji człowieka i w wyniku każdego jego «nie» otwiera nową drogę miłości". 7 Tak właśnie uczynił Bóg w raju, kiedy na „nie” Adama odpowiedział „nowym serdecznym zwróceniem się do człowieka”. Nie inaczej było w przypadku ludzkiej niewierności związanej z budową wieży Babel. Na ten bunt Bóg odpowiedział ,nowym wkroczeniem w historię zbawienia przez wybranie Abrahama". Podobny fakt dokonał się wówczas, kiedy Izrael domagał się od Boga ustanowienia króla. Życzenie to początkowo było przeciwne woli Boga, który pragnął bezpośrednio panować nad swoim ludem, jednak ,w proroctwie skierowanym do

\footnotetext{
Tamże, s. 131-133.

Tamie s. 133.

Tamże.

Tamże.
} 
Dawida sprzeciw ten przemienia się na drogę, która prowadzi potem bezpośrednio do Chrystusa, Syna Dawida. Tak więc - konkluduje Benedykt XVI - w działaniu Jezusa podobna dwustopniowość jest bez wątpienia możliwa". ${ }^{8}$ Również - wskazuje papież -6 rozdział Ewangelii według św. Jana wydaje się mówić o pewnym zwrocie, jaki dokonał się na drodze Jezusa z ludźmi. Mianowicie, po mowie eucharystycznej lud, a nawet wielu z Jego uczniów odeszło od Niego; pozostało z Nim jedynie Dwunastu. Podobne wydarzenie wyczytujemy z Ewangelii zapisanej przez św. Marka w rozdziale 8. Ewangelista opisuje w nim cudowne rozmnożenie chleba oraz zachowanie się tych, którzy chodzili za Jezusem. Po tych wydarzeniach właśnie Jezus zapowiedział mękę i wyruszył do Jerozolimy na swoją ostatnią Paschę. Papież przywołuje w tym miejscu myśl Romano Guardiniego, którą zaczerpnął z dzieła o Kościele (Theologische Traktate) napisanego w 1929 r. przez Erika Petersona, modyfikując ją przez odniesienie do Jezusa. Papież pisze, że zdaniem Guardiniego, „orędzie Jezusa zaczyna się jednoznacznie propozycją królestwa. «Nie» Izraela doprowadziło do nowej fazy historii zbawienia, do której należą śmierć i zmartwychwstanie Pana oraz Kościół pogan". ${ }^{9}$ Do wypowiedzi Guardiniego powrócimy jeszcze nieco później.

Po tych analizach papież powtarza już wcześniej postawione pytanie: „Cóż mamy powiedzieć na to wszystko?"10 Obecna jego odpowiedź jest powtórzeniem uprzedniej: „Pewien rozwój w orędziu Jezusa i nowe decyzje są zupełnie możliwe". ${ }^{11}$ Wszystko to jednak są zaledwie przypuszczenia o mniejszym lub większym stopniu prawdopodobieństwa, których nie da się wyraźnie stwierdzić. Takiej pewności nie można osiągnąć chociażby z tego powodu, że „struktura Ewangelii synoptycznych nie daje możliwości ustalenia jakiejkolwiek chronologii w kerygmacie Jezusa". ${ }^{12}$ I chociaż akcenty

\footnotetext{
Tamże, s. 133-134.

Tamże, s. 134.

10 Tamże.

1 Tamże.

12 Tamże, s. 135.
} 
dotyczące konieczności śmierci i zmartwychwstania Jezusa stają się coraz wyraźniejsze wraz z rozwojem Jego drogi, to jednak niczego one w sposób jednoznaczny nie rozstrzygają. Trzeba przecież pamiętać, że całość treści Ewangelii nie została ułożona chronologicznie, a zatem teksty synoptyków nie stanowią zapisu pozwalającego wyraźnie oddzielić od siebie „wcześniej” i „później”. Wystarczy tu przywołać np. zapis z Ewangelii według św. Marka, gdzie już w rozdziale 2 Jezus mówi o swoim odejściu. W dyskusji dotyczącej postu Jezus mówi o swoich uczniach: „Przyjdzie czas, kiedy zabiorą im pana młodego, a wtedy, w ów dzień, będą pościć" (Mk 2, 20). Jeszcze dobitniejsze świadectwo stanowią przypowieści zawierające naukę o królestwie Bożym. ${ }^{13}$ Jezus ukazuje w nich bowiem orędzie o królestwie Bożym i utożsamia swoje posłannictwo z misją Izajasza po jego spotkaniu z żywym Bogiem w świątyni. Prorokowi zostało wówczas przekazane, że jego posłannictwo najpierw sprawi przedłużenie okresu zatwardziałości i dopiero potem przyjdzie zbawienie. Jezus już w pierwszym okresie swojego przepowiadania mówił uczniom, że struktura Jego drogi będzie właśnie taka sama (Mk 4, 10nn.; Iz 6, 9nn.). Benedykt XVI wyprowadza z tego następujący wniosek: „Znaczy to jednak - pisze - że wszystkie przypowieści i całe orędzie o królestwie Bożym są postawione pod znakiem Krzyża. Wychodząc z przesłanki Krzyża i Zmartwychwstania, moglibyśmy stwierdzić, że właśnie Krzyż stanowi krańcowy, radykalny przejaw bezwarunkowej miłości Boga - miłości, w której, pomimo z gruntu negatywnej postawy ludzi, daje On siebie samego, bierze na siebie to «nie» ludzi, włączając je tym sposobem we własne «tak» (zob. 2Kor 1,19). Tę interpretację przypowieści i ich orędzia o królestwie Bożym - interpretację w duchu teologii Krzyża - znaleźć można również w paralelnych tekstach pozostałych synoptyków (zob. Mt 13, 10-17; Łk 8, 9n.)". ${ }^{14}$ Papież twierdzi przeto, że perspektywa krzyża jest obecna od samego początku nauczania Jezusa i przenika całość Jego orędzia. Uzasadnienie swoje ogranicza do zupełnie wystarczających

\footnotetext{
13 Tamże.

14 Tamże, s. 136.
} 
dwóch argumentów. Pierwszy z nich wywodzi się z Kazania na Górze zapisanego przez św. Mateusza. Wszystkie wypowiedziane tam błogosławieństwa są przeniknięte perspektywą krzyża, co ze szczególną wyrazistością zostało sformułowane w ostatnim z nich: „Błogosławieni, którzy cierpią prześladowanie dla sprawiedliwości, albowiem do nich należy królestwo niebieskie. Błogosławieni jesteście, gdy wam urągają i prześladują was, i gdy z mego powodu mówią kłamliwie wszystko co złe o was. Cieszcie się i radujcie, albowiem wielka jest wasza nagroda w niebie. Tak bowiem prześladowali proroków, którzy byli przed wami" (Mt 5, 10nn.). Nie można też pominąć epizodu o odrzuceniu Jezusa w Nazarecie ukazanego przez Łukasza na początku opisu Jego drogi. Kiedy Jezus odniósł do siebie proroctwo Izajasza mówiące o wypełnieniu się obietnicy roku łaski Pana (Łk 4, 18), wówczas Jego ziomkowie zawrzeli gniewem, wyrzucili Go z miasta, wyprowadzili Go na stok góry, aby Go strącić (Łk 4, 29). ${ }^{15}$ Papież opatruje to następującym komentarzem: „Łukasz, który bardzo starannie ułożył swoją Ewangelię, oraz [wyżej przypomnianą] scenę zamieścił zupełnie świadomie, jako swoisty nagłówek dla całej działalności Jezusa". ${ }^{16}$ Nie ma zatem sprzeczności - kontynuuje papież - między radosnym głoszeniem Dobrej Nowiny i przyjęciem przez Niego krzyża, ,przeciwnie - pisze dalej - to radosne orędzie łaski całą swą głębię osiąga dopiero przez przyjęcie śmierci i jej przemianę". ${ }^{17}$

Całość myśli papieża Benedykta XVI w interesującym nas aspekcie można zatem streścić następująco. Nie jest samo w sobie sprzeczne utrzymywanie, że Jezus chciał pojednać ludzi z Ojcem przez przyjęcie przez nich głoszonego im królestwa Bożego, a kiedy ludzi odrzucili przynoszącego im Dobrą Nowinę Syna Bożego, Ten, który do końca ich umiłował, przyjął to odrzucenie wraz ze skrajnymi tego konsekwencjami, czyli męką i śmiercią na krzyżu. Jednak, jak zaznaczyliśmy wyżej, nie można tego w żaden sposób dowieść przez

\footnotetext{
15 Tami̇e, s. 135-137.

16 Tamże, s. 137.

17 Tamże.
} 
odwołanie się do zapisów Ewangelii. Ponieważ brak jest dostatecznych źródłowych podstaw, inne schematy dotyczące drogi zbawienia człowieka mogą być jedynie hipotezą, owocem czystej spekulacji.

Na zakończenie niniejszego paragrafu odwołamy się jeszcze do pracy o. Tadeusza Dionizego Łukaszuka zatytułowanej Ty jesteś Chrystus, Syn Boga żywego. Jest to dzieło autorstwa skrupulatnego badacza i znawcy teologii dogmatycznej, prezentujące stanowiska teologów odnośnie do badanej przez nas kwestii. Odwołanie to pozwoli nam uchwycić przekonanie teologów bez powtarzania dokonanych już analiz.

Z przedstawionych tam badań wynika jasno, że krzyż, chociaż bardzo trudny w zrozumieniu, to jednak był konieczny w dziele odkupienia. „Zrozumienie Krzyża - pisze o. Łukaszuk - z trudem przychodziło pierwszym chrześcijanom i to zarówno tym, którzy wywodzili się z pogan i mieli mentalność ukształtowaną przez filozofię grecką, jak i dla tych, którzy wywodzili się z żydowskiego zrozumienia Pism Starego Testamentu. Działo się to z różnych powodów, niemniej trudność ta dotyczyła obydwóch grup". ${ }^{18}$ Pomimo skandalu krzyża, jak pisze Tadeusz D. Łukaszuk, „fakt «Krzyża» powoli doznawał wszechstronnego usprawiedliwienia, które dokonywało się w świetle doświadczeń paschalnych, przy równoczesnym wczytywaniu się w sens zapowiedzi starotestamentowych. Stawało się dla wiernych coraz bardziej jawne, że taki był plan Boży, zgodnie z którym Chrystus miał przez krzyż i cierpienie wejść do chwały swojej (... ) U Synoptyków - kontynuuje o. Łukaszuk - spotykamy mocne podkreślenie dwóch wymiarów tajemnicy męki Jezusa: $\mathrm{z}$ jednej strony przedstawiają krzyż jako chciany przez Ojca i aprobowany w posłuszeństwie przez Syna, a z drugiej opisują go jako fakt skierowany na wyzwolenie ludzi z ich grzechów. (...) Krzyż jawi się w tych tekstach nie w pozycji przypadkowego załamania się planów Bożych, lecz w roli właściwego ich wypełnienia". ${ }^{19}$ Następnie o. Łukaszuk

18 Szerzej zob. T. D. Łu k a s z u k, Ty jesteś Chrystus, Syn Boga żywego. Dogmat Chrystologiczny w ujęciu integralnym, Kraków 2000, s. 124.

19 Tamże. 
przywołuje treść Listu do Hebrajczyków, w którym natchniony autor wykazuje, że sam rytualizm ofiarniczy, sprawowany według starych schematów, nie wystarczał do odpuszczenia grzechów, jako że do tego potrzebna była w samych ,składanych ofiarach zgodność woli ofiarującego z wolą Bożą, czyli potrzebne było doskonałe posłuszeństwo", co doskonale dokonało się właśnie w ofierze Jezusa Chrystusa. Przytacza w tym miejscu również słowa G. L. Müllera, który również zdecydowanie podkreśla, że dzięki posłuszeństwu Jezusa na Kalwarii stał się On podmiotem, tzn., że On sam był żertwą ofiarną, którą On sam ofiarował. Niegodziwi sędziowie i okrutni kaci byli jedynie narzędziem wypełnienia się planów Bożych; byli jedynie przedstawicielami zagubionego świata, któremu Bóg, przez Jezusa, ofiaruje zbawienie. ${ }^{20}$

Interpretacja wyników badań przeprowadzonych przez o. Łukaszuka może być zatem następująca. Pan Bóg mógł odkupić człowieka w taki sposób, w jaki sam suwerennie postanowił. Nikt przecież nie może narzucać Bogu swojej woli, wszak Jego wola jest wyrazem Jego absolutnej doskonałości, w tym, oczywiście i absolutnie doskonałej wszechmocy. A zatem, chociaż Bóg mógł wybrać inną drogę pojednania człowieka ze sobą, to jednak, mocą swojej woli, zechciał dokonać tego dzieła przez mękę i śmierć swego Jednorodzonego Syna na krzyżu. Dlaczego? To pozostaje tajemnicą Bożą. Wspomniany autor pisze bowiem tak: ,Krzyż Chrystusa jest tak głęboką i wielką tajemnicą, że się jej nie da wypowiedzieć w jednej teologicznej koncepcji. Ona te ramy rozsadza, żądając nowych dopowiedzeń, które z kolei okażą się również nie wystarczające. Przy założeniu wspomnianej owej niewystarczalności, można wszakże sobie pozwolić na wskazanie jeszcze jednej funkcji krzyża $\mathrm{w}$ dziele zbawienia. W i a d o mo powszechnie, że Chrystus i bez krzyża mógłby zdobyć dla swoich braci w człowieczeństwie te dary Boże, które są przejawem miłości Ojca. Wszelako krzyź świadczy bardzo skutecznie o tym, że wola Ojca stanowi najwyższą wartość,

20 Tamże, s. 128, oraz przyp. 230. 
dla której warto oddać ws zystko... Na Kalwarii zatem urzeczywistniło się wydarzenie zgoła niesłychane, mianowicie złożenie takiego świadectwa miłości do Ojca i do braci, które przewyższa wszystkie fałszywe świadectwa naszych grzechów..."21

Ojciec Łukaszuk przywołuje także słowa św. Augustyna, który na pytanie, czy Bóg mógł zbawić człowieka bez męki krzyżowej, odpowiedział sobie współczesnym: „Niewątpliwie mógł, ale gdyby tak postąpił, to również nie przypadłoby do gustu waszej głupocie". ${ }^{22}$

Uzasadniając swoje stanowisko, o. Łukaszuk odwołuje się także do myśli św. Tomasza z Akwinu i podsumowuje je stwierdzeniem: „Tomasz odstępuje jednoznacznie od podtrzymywania tezy o metafizycznej konieczności męki krzyżowej, zadowalając się stwierdzeniem o wysokiej konieczności tego objawionego faktu. Można mówić jedynie o jego względnej konieczności, uwarunkowanej Bożą uprzednią wiedzą $\mathrm{i}$ jej przejawem w postaci prorockich zapowiedzi. Uwzględniając wiedzę i dokonaną zapowiedź, trzeba powiedzieć, że w ich świetle męka Pana była konieczna". ${ }^{23}$ A zatem - kontynuuje krakowski teolog krzyż jawi się jako naturalna konsekwencja sytuacji Syna Bożego, wcielonego w takim świecie, w którym panuje grzech. Jezus, będąc solidarnym z każdym człowiekiem, nie mógł nie działać dla wyzwolenia każdego z niewoli grzechu i śmierci. „Nie mógł także nie angażować się w odnowienie oblicza świata, na którym powinna rozbłyskać przyznana Mu przez Boga chwała". ${ }^{24}$ Jego misja i Jego osoba została jednak przez ludzi odrzucona. Orędzie Jezusa, urzeczywistnione w głoszonym słowie oraz świadectwie czynów (cudów), jedynie prowokowało siły zła i rodziło aktywną kontrakcję (por. J 15, 18). ,Żydzi i poganie podjęli zgodnie akcję, prowadzącą do eliminacji Jezusa ze świata, ukształtowanego w dużej mierze przez ich

21 Tamże, s. 138.

22 Tamże, s. 132, oraz przyp. 238.

23 Tamże, s. 133; Św. To m a s z z A k w i n u, STh., III, q. 46-50.

24 T. D. Łu k a s z u k, Ty jesteś Chrystus, Syn Boga żywego, s. 136. 
wygórowany egoizm". ${ }^{25}$ I właśnie dla tych racji krzyż - pisze o. Łukaszuk - był konieczny. „Jeśli mówimy, że Ojciec chciał krzyża - wyjaśnia - to nie trzeba rozumieć tego w tym sensie, że chciał czegoś, co byłoby dodane specjalnym dekretem do Jezusowego życia, lecz że po prostu chciał wiernej miłości Jezusa, która byłaby tak niezachwiana w pełnieniu woli Ojca, mającego na względzie dobro ludzi, iżby nie wahała się podjąć się ryzyka śmiertelnego starcia z grzesznym światem. Jezus to ryzyko podjął, dowodząc swojej niezachwianie wiernej miłości względem Boga i ludzi... Chrystu s owe przebłaganie, spełnione przez śmierć krzyżową, nie jest niczym innym niż spełnieniem zleconego $\mathrm{Mu} \mathrm{z}$ a d a n i a, by był przekazicielem Bożego zbawienia, podjętym i dopełnionym w ludzkiej wolności". ${ }^{26}$

Wydaje się, że niektóre zdania z wypowiedzi o. Łukaszuka mogłyby poddawać się swoistej reinterpretacji, na skutek czego dałyby się uzgodnić ze wzmiankowanym już stanowiskiem R. Guardiniego, ponieważ jednak autor nie wspomina o takiej możliwości, zatem, ażeby pozostać wiernym zapisanemu przez niego tekstowi, przedstawioną w nich opinię, ujętą całościowo, należy umiejscowić pośród tych, które wskazują, że krzyż był koniecznym środkiem naszego odkupienia.

\section{Odkupienie człowieka mogło się dokonać na innej drodze niż przez śmierć Syna Bożego}

Spróbujmy teraz poszukać argumentów, które mogłyby przemawiać za inną drogą prowadzącą do pojednania człowieka z Bogiem niż ukazane w poprzednim punkcie. Co zatem, jakie fakty, możemy przedstawić w paragrafie: sed contra.

Na początku zwróćmy uwagę na znajomość tekstów biblijnych przez przeciętnego Izraelitę. Zapytajmy zatem o sposób zdobywania wiedzy biblijnej przez współczesnych Jezusowi Żydów. Jest to kwestia

\footnotetext{
25 Tamże.

26 Tamże, s. 136-137.
} 
o dużym znaczeniu dla opracowania podjętej tu problematyki. Trzeba przyznać, że panuje powszechna zgoda co do tego, że Żydzi bardzo cenili sobie naukę i - co zatem idzie - dbali o kształcenie młodych pokoleń. Pierwszy stopień szkolenia związany był z Synagogą, a edukację rozpoczynały już pięcioletnie dzieci i to zarówno te, które pochodziły z rodzin bogatych, jak i z biednych. Nauka odbywała się w ten sposób, że uczniowie siadali na ziemi wokół nauczyciela i chórem z pamięci powtarzali dosłownie zdania, które on wypowiadał. Dzieci, jak czytamy w Ewangelii, korzystały z tej metody nawet podczas zabawy. Święty Łukasz pisze o malcach siedzących na placach publicznych i odpowiadających sobie nawzajem wyuczonymi wersetami: „Graliśmy wam na flecie, a wy nie tańczyliście, lamentowaliśmy, a wyście nie płakali” (Łk 7,32).W szkole uczono przede wszystkim Tory; to ona służyła do nauki alfabetu. Natomiast gramatyki, historii, geografii uczono za pomocą Biblii. Józef Flawiusz chwalił się, że już w czternastym roku życia znał całą Biblię, a św. Paweł w Liście do Tymoteusza pisze, że adresat „od dzieciństwa znał święte Pisma" (2Tm 3, 14).

Co do kształcenia dziewcząt istniała pewna różnica zdań; jedni byli za, inni przeciw. Przykład Maryi dobitnie jednak świadczy, że i dziewczęta otrzymywały rzetelną edukację, wszak w hymnie Magnificat doliczono się aż trzydziestu reminiscencji biblijnych. Świadectwo to pokazuje, że i dziewczęta, doskonale znały Pismo.

Po ukończeniu nauczania podstawowego, uczeń mógł podjąć studia wyższego stopnia, co miało miejsce np. w przypadku Szawła z Tarsu. Traktat talmudyczny mówił, że dziecko w piątym roku życia ma rozpocząc święte nauczanie, w dziesiątym winno studiować tradycję, w trzynastym - zobligowane jest do pełnego poznania Prawa Jahwe i stosowania jego przepisów w praktyce, natomiast w piętnastym musi rozpocząć pogłębianie nabytych wiadomości. ${ }^{27}$ Wynika z tego, że każdy Żyd, pominąwszy przykłady jednostek potwierdzających regułę, znał znakomicie teksty Biblii, w tym te, które mówią o męce

27 D. R o p s, Życie codzienne w Palestynie w czasach Chrystusa, tłum. J. L a s o c k a, Poznań-Warszawa-Lublin 1964, s. 153-156. 
i śmierci Mesjasza, jak chociażby już wcześniej wspomniane proroctwa Izajasza z rozdziału 53 czy Psalm 22.

Co uderza, co musi uderzać, co musi zastanawiać i prowokować, to fakt, że Żydzi nie wiązali tych zapowiedzi z Mesjaszem. Dobitną ilustrację takiej sytuacji stanowi zachowanie św. Piotra. Kiedy Jezus mówił o swojej męce i śmierci krzyżowej (mówił również o zmartwychwstaniu), wówczas ten pierwszy spośród apostołów wypowiedział jakże wymowne, nabrzmiałe w treści i dosadnie świadczące o ukształtowaniu jego świadomości słowa: „Panie, niech C i ę B ó g b r o n i! Nie przyjdzie to n i g d y na Ciebie" (Łk 16, 22). Fakt, że Jezus został odrzucony przez swój naród jest potwierdzeniem tego, iż proroctwa, które my dziś określamy mianem ,,proroctw mesjańskich”, dla starozakonnych Żydów wcale za takie nie uchodziły. Również licznych cudów dokonanych przez Jezusa Jemu współcześni nie chcieli uznać dowód Jego boskości. Daniel Rops, za G. Lagrangem, pisze, że chociaż dzieła dokonane przez Jezusa były niezwykłe, to w oczach Izraelitów wcale nie musiały stanowić dowodu na to, że Jezus jest Mesjaszem. Przecież i prorocy dokonywali niezwykłych znaków, a Eliasz i Elizeusz przywracali nawet życie zmarłym. ${ }^{28}$ „Chrystus, będąc tym, kim był, nie miał żadnych danych na to, aby Go uznano za Mesjasza" - pisze D. Rops. ${ }^{29}$ Powodów po temu, oprócz podanych powyżej, było wiele. Przeszkodę taką stanowiły najpierw racje polityczne. Od Mesjasza oczekiwano nade wszystko dokonania odwetu, co - jak podkreśla D. Rops - stanowiło naturalne pragnienie narodu upokorzonego i uciemiężonego. Bardzo powszechne wśród Izraelitów było wyobrażenie Mesjasza, jako króla okrytego chwałą, wodza strasznego dla nieprzyjaciół, takiego, który dokona pomsty za krzywdy poniesione przez Izrael. To właśnie z takiego nastawienia zrodziło się pytanie, które Jezusowi - nawet po Jego zmartwychwstaniu - postawili apostołowie: „Panie, czy w tym czasie przywrócisz królestwo Izraela?” (Dz 1, 6). ${ }^{30}$ Całkiem słuszne zatem wydaje się

\footnotetext{
28 Tamże, s. 626, oraz przyp. 57.

29 Tamże, s. 621.

30 Tamże, s. 621-622.
} 
podsumowanie Daniela Ropsa, który pisze, że ,jeśli chodzi o obraz Mesjasza cierpiącego, umęczonego dla zbawienia świata, jaki można było odtworzyć sobie na podstawie kilku krótkich fragmentów zawartych w świętej Księdze, trzeba raz jeszcze powtórzyć, że był on «zupełnie obcy judaizmowi w epoce zbliżonej do ery chrześcijańskiej». Więcej nawet, w opinii tego dumnego narodu obraz ten miał w sobie coś gorszącego, bowiem porażka nie wydawała mu się nigdy znakiem pochodzącym od Boga. Oto dlaczego widok człowieka ubiczowanego, ociekającego krwią, oplutego nie wzbudził wśród zebranych żadnego uczucia litości. Ten, dla Żydów śmieszny Mesjasz, zasługiwał na krzyż". ${ }^{31}$

Nie tylko krzyż stanowił niezrozumiałą rzeczywistość dla Izraelity. Również zmartwychwstanie było dla Żydów nie do pojęcia. Wyraźnie świadczy o tym postawa św. Piotra, który na słowa Jezusa o swojej męce, śmierci, ale przecież i zmartwychwstaniu, odpowiedział przytaczane już wcześniej przez nas słowa: „Panie nie przyjdzie to nigdy na Ciebie”. Papież Benedykt XVI pisze: „Było to coś nieoczekiwanego również dla uczniów. Coś, z czym powoli dopiero musieli się uporać. Wprawdzie dla Żydów znane było zmartwychwstanie na końcu czasów. To nowe życie wiązało się z początkiem nowego świata i z tej perspektywy było też czymś jak najbardziej zrozumiałym: jeśli istnieje nowy świat, to jest w nim także nowy sposób życia. Jednak zmartwychwstanie, jako przejście w stan definitywny, odmienny, pojawiające się pośród starego, nadal istniejącego świata, nie było przewidziane i dlatego także nie było z początku zrozumiałe. Stąd zapowiedź Zmartwychwstania pozostała zrazu niezrozumiała dla uczniów". 32

Jakiego przeto Mesjasza oczekiwał Izrael? Izraelici od dzieciństwa studiujący święte Pisma żyli obietnicą Mesjasza, z którym wiązali nastanie epoki szczęśliwości. Postawa ta była szczególnie wyrazista właśnie w czasach narodzenia Jezusa, kiedy to Izrael przeżywał czas szczególnie smutny spowodowany okupacją rzymską. ,Tysiące

\footnotetext{
31 Tamże, s. 622.

32 J. R at z inge r/ B e ne dy k t XVI, Jezus z Nazaretu, cz. 2, s. 261.
} 
znaków wskazuje, jak bardzo żywe było w chwili narodzenia Jezusa owo oczekiwanie Mesjasza" - pisze D. Rops. ${ }^{33}$ Powyższą tezę łatwo wesprzeć zapisami ewangelistów. Pewną niecierpliwość, która zawsze konstytuuje wyczekiwanie $\mathrm{z}$ łatwością odnajdujemy w pytaniu, które stawiano św. Janowi Chrzcicielowi: „Kim jesteś”? „Czy ty jesteś Mesjaszem?" (por. Mt 3,15n.) czy też w przesłaniu, które Jan Chrzciciel przekazał Jezusowi: „Czy Ty jesteś Tym, który ma nadejść, czy też innego mamy oczekiwać?” (Mt, 11, 3). Również stwierdzenie Samarytanki wyraża pewność, którą niesie w sobie ta niezwykła obietnica i związane z nią oczekiwanie: „Wiem, że przyjdzie Mesjasza” - mówi niewiasta do Jezusa. Ta sama atmosfera zawarta jest w pytaniu pielgrzymów skierowanym do Jezusa: „Dokądże będziesz trzymał nas w niepewności? Jeżeli jesteś Chrystusem, powiedz nam otwarcie" (J 10, 24). Ów entuzjazm ujawnił się w Niedzielę Palmową, kiedy tłum był gotowy na to, ażeby ogłosić Jezusa królem, Mesjaszem Izraela. ${ }^{34}$ Tę samą w swej treści myśl wypowiadają rozmówcy Jezusa na drodze do Emaus, którzy wyznają: „A myśmy się spodziewali, że On właśnie miał wyzwolić Izraela" (Łk 24, 21). Kontynuując odpowiadanie, jeszcze raz posłużmy się słowami Daniela Ropsa, w których wyjaśnia on, że wizja Mesjasza chrześcijan i Żydów były dwoma różnymi zrozumieniami. „Trzeba przyznać - pisze Rops - że na tym punkcie znaczna większość dokumentów rysowała obraz dziwnie odmienny od tego, w którym zazwyczaj chrześcijanie rozpoznają Mesjasza. (...) Poniżony Izrael oczekiwał swego mściciela lub co najmniej wybawcy, który przywróciłby mu jego miejsce na ziemi. To leżało w porządku rzeczy. I to do tego stopnia, że nawet uczniowie Chrystusa pozostaną wierni temu obrazowi i kilkakrotnie będą Go pytali, czy nie założy wreszcie swego królestwa na ziemi i czy nie da im udziału w swym chwalebnym królowaniu.

A przecież każdy, kto uważnie czytał święte Pisma, mógł w nich dostrzec obraz inny, o ileż bardziej wzruszający. Obraz Mesjasza

33 D. R o p s, Życie codziennew Palestynie w czasach Chrystusa, s. 599-600.

34 Tamże, s. 601. 
bolesnego, biorącego na siebie trudy ludzkie, ich trwogę i cierpienia, oddającego swe życie na odkupienie ich grzechów". ${ }^{35}$

I chociaż nie były im nieznane prorockie teksty Izajasza mówiły o Mesjaszu, jako „Mężu Boleści” (Iz 53, 4), „Baranku prowadzonemu na rzeź" (Iz 53,7) czy też przesłanie Zachariasza głoszące,

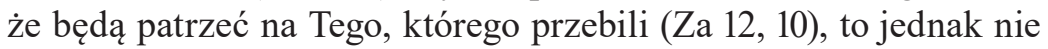
z nimi wiązali Żydzi opis Mesjasza. ${ }^{36}$ Daniel Rops tak konkluduje swoje analizy związane z powyższymi tekstami: „Ale z pewnością niewielu było Żydów myślących o tych prorockich wersetach Ksiąg świętych w chwili, gdy - jak to głosił Micheasz - w Betlejem, «malutkiej, między tysiącami» (por. Mi 5, 1), judzkiej mieścinie rodziło się bez dachu nad głową przybrane Dziecię ubogiego cieśli..." ${ }^{37} \mathrm{Czy}$ była to tylko pomyłka, błędne odczytanie świętych tekstów przez Żydów? Czy może istniała dwojaka możliwość ich odczytania; nie tyle podwójna droga, ile jedna droga, zawierająca w sobie potencjalnie dwa sposoby na zaktualizowanie, na zrealizowanie się pojednania człowieka z Bogiem?

Wspomnieliśmy już o takiej hipotetycznej sytuacji przy okazji analizy tekstów papieża Benedykta XVI. Chyba najwyraźniej i jednoznacznie wyraził to Romano Guardini. Pisał on, że „Jezus na początku nie mówił o swojej śmierci. Gdyby ludzie otworzyli swe serca, spełniłyby się przepowiednie proroków. Zbawienie dokonałoby się poprzez głoszenie Dobrej Nowiny i wiary, historia zmieniłaby bieg. Dopóki taka możliwość istniała, Pan Jezus zdaje się nie wspominać o swojej śmierci, w każdym razie czyni to w sposób bardzo zawoalowany. Ale potem przywódcy zatwardzają serca, lud odwraca się i Pan Jezus - nie dowiemy się, w jakiej ciężkiej godzinie próby - wchodzi na drogę śmierci, aby dokonać zbawienia..." ${ }^{38}$

Chociaż odkupienie człowieka przez mękę i śmierć Jezusa na krzyżu znajduje silne umocnienie w starotestamentalnych

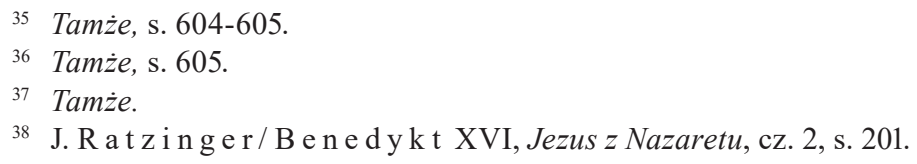


wypowiedziach, to jednak nie są one radykalnie jednoznaczne w swoim przekazie. Świadczy to tym ich interpretacja przez Izraelitów. Również papież Benedykt XVI przyznaje, że ich przesłanie musiało zostać na nowo odczytane w świetle zaistniałych faktów. Pisze on: „Proces stawania się wierzącym ma podobny przebieg, jak postawa wobec Krzyża. O Mesjaszu ukrzyżowanym nikt nie myślał. Ale teraz był to fakt i na podstawie tego faktu trzeba było odczytać Pismo na nowy sposób... Nowe odczytanie Pisma mogło rzecz jasna zacząć się dopiero po Zmartwychwstaniu, ponieważ dopiero przez nie Jezus został uwierzytelniony jako posłaniec Boga. Teraz trzeba było szukać w Piśmie obydwu, Krzyża i Zmartwychwstania, wyjaśniając je w nowy sposób i tą drogą dochodzić do wiary w Jezusa jako Syna Bożego". ${ }^{39}$

\section{Proroctwa i ich wypelnienie: trudności w interpretacji}

Co może do tego, najbardziej przejmującego wydarzania - śmierci Syna Bożego, na skutek podniesienia ręki stworzenia na Stwórcę dopowiedzieć ludzki rozum? Czy cokolwiek może? Czy nie powinien w zawstydzeniu zamilknąć, tak jak uczyniło to słońce, które w godzinie śmierci Syna Bożego ,zaćmiło się i mrok ogarnął całą ziemię" (por. Mk 27, 44-45), jak gdyby nie chciało patrzeć, na to, co człowiek zgotował swemu Bogu? Spróbujmy jednak pozwolić ludzkiemu rozumowi spojrzeć na ten niepojęty dramat, aby w świetle naturalnego rozumu może jeszcze lepiej zrozumieć ową niepojętą Miłość Boga ku człowiekowi.

Wydaje się, że teza tak jasno postawiona przez R. Guardiniego dogłębniej wyjaśnia miłość Bożą, a co za tym idzie, również dosadniej ujawnia niegodziwość człowieka, a jednocześnie wyraźniej wzywa człowieka do dawania Bogu odpowiedzi w nieustannie intensyfikującej się, wzrastającej miłości, miłości coraz bardziej wierniejszej i żywej. Usuwa też pewne trudności w wyjaśnieniu postaw ludzkich wobec zapowiedzi zawartych w proroctwach.

39 Tamże, s. 261. 
Jakie bowiem trudności napotyka ludzki rozum w koncepcji ukazującej krzyż, jako wolę Ojca? Stanowi ona dla myśli ludzkiej pewien labirynt niemający oświetlonego wyjścia. Są to tylko myśli ludzkie, a więc ograniczone, dlatego muszą być wyrażane ze stosowną pokorą, niemniej jednak rozum ludzki pyta: Jeżeli taka była decyzja Boga, ażeby Syn Boży oddał za ludzi swoje życie na krzyżu, to czy człowiek miałby inne wyjście, jak właśnie tylko dokonanie zabójstwa Syna Bożego? Wola Boża bowiem musiałby być dopełniona, inaczej nie dokonałoby się zbawienie. Zatem, albo musiałby znaleźć się przynajmniej jeden niegodziwiec - zabójca Syna Bożego, albo człowiek unicestwiłby zamiar Boży mający na celu dzieło odkupienia. Gdyby bowiem zabrakło przynajmniej jednego zabójcy, odkupienie nie mogłoby się dokonać. Stajemy tutaj z jednej strony wobec pytania o wolną wolę człowieka, z drugiej - o doskonałość i wszechmoc Boża. Przecież, jeżeli coś musi się dokonać, to takiemu faktowi nie można przypisać źródłowego działania wolnej woli. Tam bowiem, gdzie jest konieczność, tam nie ma wolności. A jak można by pomyśleć, że Bóg skazał kogoś na tak potworną zbrodnię? Takie myślenie kłóci się z najbardziej elementarnymi prawidłami zdroworozsądkowego rozumowania. Bóg, będąc samym Dobrem, nie może być przyczyną jakiegokolwiek zła, a cóż dopiero zła najgorszego. Wydaje się, że stajemy wobec oczywistej aporii.

Kiedy natomiast przedstawimy drugą sukcesję zrozumienia ekonomii zbawienia wskazujemy, że Syn Boży stał się człowiekiem, aby dokonać odkupienia; przyszedł jako Miłość gotowa na wszystko, aż do oddania swojego życia. Syn Boży przyszedł, aby nas zbawić, a Jego absolutnie doskonała Miłość, potencjalnie zawierała każdy sposób zaktualizowania się, a więc była gotowa na wszystko, aż na mękę i śmierć. Człowiek zaś był w możności, czyli miał możliwość przyjęcia misji Syna Bożego, albo Go odrzucenia i - niestety - wybrał tę drugą perspektywę.

Wypowiadając się na ten temat, o. Jacek Salij najpierw zapytał o to, czy Jezus był zdeterminowany proroctwami? I odpowiedź jego była, oczywiście, negatywna. „Przecież On jest Synem Bożym! - pisał. - Jako Syn Boży, w przeciwieństwie do nas wszystkich, mógł On 
suwerennie wybierać sobie te okoliczności swojego przyjścia, jakie uznał za stosowne". ${ }^{40}$ To nie proroctwa wyznaczały dzieje Jezusa, ale On wyznaczał treści proroctw. Syn Boży, jako absolutnie doskonały nie mógł być zobligowany proroctwami. Ale co z niedoskonałym człowiekiem? Czy człowiek nie musiał wykonać zapowiedzi odnoszących się do niego? Ojciec Salij zatem pyta: Czy, ażeby te zapowiedzi zostały wypełnione, ludzie nie zostali ku temu przeznaczeni? Szczególnie niepokojącym jest przypadek Judasza. Jeżeli Jezus miał być zdradzony, to musiał znaleźć się Jego zdrajca. Ta nieszczęsna konieczność musiała się dokonać, a jej wypełnienie przypadło Judaszowi. A zatem, czy raczej nie należałoby mu współczuć, niż go za to obwiniać? - pyta o. Salij. ${ }^{41}$

Odpowiadając na postawione pytanie przywołuje on tekst Psalmu 22 oraz Pieśni o Słudze Pańskim (Iz 50, 4-4; 52, 13-53). We wskazanych opisach męka Mesjasza stanowi tylko tło, albowiem po pierwsze, proroctwa ukazują Jego całkowite zawierzenie się Bogu pośród straszliwej udręki, a po drugie, opisują Jego ostateczne zwycięstwo; zwycięstwo, które będzie nie tylko Jego zwycięstwem, ale wszystkich ludzi. Nie można jednakże zaprzeczyć, że owe proroctwa zapowiadały również okrutną mękę i śmierć Mesjasza. Ażeby to mogło się wypełnić musieli się znaleźć prześladowcy i kaci, ale - jak pisze o. Salij - „takich nie trzeba długo szukać, tacy się sami znajdą”. Takie postawy ludzkie swoją przyczynę mają w grzechu, który głęboko wszedł w ludzkie dzieje. Przecież, jak argumentuje przywołany tutaj teolog, zanim nastąpiła męka i śmierć Chrystusa, kilkakrotnie znaleźli się tacy, którzy chcieli Go zabić, o czym zaświadczają Ewangelie (Łk 4, 29n.; J 7, 30. 44; 8, 59; 10, 31.39). „Pan Bóg z całą pewnością nikogo nie determinuje do zła. Jest raczej odwrotnie: Moc Boża wielokrotnie chroni nas przed czynieniem jakiegoś wielkiego zła, do którego, niestety, bylibyśmy zdolni” - pisze o. Salij. ${ }^{42}$

\footnotetext{
40 J. S a li j, Tajemnice Biblii, Poznań 2003, s. 159-160

${ }^{41}$ Tamże, s. 160.

42 Tamże.
} 
Odnośnie zaś do osoby i czynu Judasza o. Salij przedstawia następujące wyjaśnienie. Proroctwa odnoszące się do niego „dotyczą ogólnie krzywdy wyrządzonej skrzywdzonemu przez kogoś bliskiego. Przytacza się tu zwłaszcza trzy takie proroctwa: sprzedanie Józefa za garść srebrników przez własnych braci (Rdz 37, 28) oraz dwie skargi psalmisty na zdradę i niewdzięczność przyjaciół (Ps 41, 10; 109, 4nn.). Wpatrując się w te teksty - raczej niezbyt szczegółowo zapowiadające zdradę ze strony kogoś bliskiego - możemy powiedzieć z całą pewnością, że Judasz nie musiał zdradzić swojego Mistrza. Więcej, mógł Go nie zdradzić i nie powinien był go zdradzić. Ale jakby się wtedy spełniły powyższe proroctwa? One przecież i tak spełniły się nie tylko na Judaszu. Judasz nie był jedynym człowiekiem bliskim Jezusowi i wiele Mu zawdzięczającym, jaki się znalazł wśród Jego wrogów i sprawców Jego męki. Wśród prześladowców Jezusa z pewnością byli również inni ludzie, którzy $\mathrm{Mu}$ wiele zawdzięczali, może doznali Jego cudu itp. Judasz to, owszem, konkretny nieszczęsny człowiek. Ale to także ktoś prezentujący postawę, jaką wówczas prezentowali również inni, a która zdarza się, niestety, również w naszym życiu". ${ }^{43}$

Grzeszność ludzka, mająca swe korzenie w grzechu pierworodnym, dokonała takiej destrukcji natury ludzkiej, doprowadziła do takiego jej zepsucia moralnego, że z całą pewnością znaleźliby się ludzie, a przynajmniej jeden taki człowiek, który by dokonał zabójstwa Syna Bożego. $Z$ całą również pewnością znalazłby się pomiędzy ludźmi jakiś zdrajca, jakiś morderca. Wyjaśnienia o. Salija są przekonujące i dostatecznie wymownie wykazują, że żaden człowiek, z Judaszem włącznie, nie był ,przeznaczony” do zdrady czy przybicia do krzyża Syna Bożego. W ten sposób wyjaśnia się kwestia wolnej woli człowieka, wolnej, a więc niczym w radykalny sposób niezdeterminowanej. Ale właśnie dlatego, że człowiek jest wyposażony w wolną wolę, wydaje się, że nie jest samo w sobie sprzeczna sama w sobie hipoteza, że mógł przyjąć głoszoną przez Jezusa Dobrą Nowinę, nawrócić się i nie doprowadzić do męki i śmierci Syna Bożego.

\footnotetext{
43 Tamże.
} 
Do twierdzeń o. Jacka Salija, jak to już napisaliśmy - bardzo przekonujących, z obowiązku rzetelnie prowadzonej analizy, musimy dodać, że mimo ich rzetelności, cechuje je daleko posunięta ogólność. Do opinii głoszącej, że zawsze znalazłby się jakiś niegodziwiec, który by zdradził, zamordował, można przecież dodać pytanie: A co by było, gdyby jednak się nie znalazł? Trzeba też dodać, że odnotowuje się pojawiające się przekonanie, że stwierdzenia, które znamionuje wielka ogólność, w zasadzie nie dają się falsyfikować. ${ }^{44}$

\section{Próba podsumowania}

Jak można by wyjaśnić drogę odkupienia człowieka bez ofiary męki i śmierci krzyżowej Mesjasza? W teologii przewijają się dwa terminy, który opisują istotę pojednania Boga z człowiekiem. Są nimi: prawda i pochodząca z niej, czystość. Kiedy Jezus stanął przed Piłatem, tak streścił cel swojego przyjścia na świat; , ,Ja się na to narodziłem i na to przyszedłem na świat, żeby dać świadectwo prawdzie” (J 18, 36). Prawda jest światłem, bo tylko prawda ukazuje „co jest czym”, czyli ukazuje istotę rzeczy, którą definiuje się jako „to, co sprawia, że dana rzecz jest tym, czym jest”. Kłamstwo przesłania, deformuje, jest przekłamaniem. Kłamstwo jest antyświatłem, zachowuje wszelkie pozory światła, ale celem jego działania nie jest rozpoznanie prawdy, ale wprowadzenie w stan fałszywy. Kłamstwo jest ciemnością i oszukuje, że oświeca, że pozwala poznać, podczas gdy dąży do zamroczenia, do wprowadzenie w ułudę, w nieprawdę, w ciemność.

Święty Jan Apostoł pisze: „Bóg jest światłością, a nie ma w Nim żadnej ciemności (1J, 1, 5). Oraz w innym miejscu: „W Nim [w BoguSłowie] było życie, a życie było światłością ludzi i ciemność jej nie ogarnęła" (J, 1, 4-5). Bóg w swoim Słowie ofiarował ludziom Światło Prawdy, Światło, które jest prawdziwym Życiem. Nie ma

44 „Wysunę tezę, że teorie o znacznym stopniu ogólności nie są podatne na falsyfikację..."; I. G. B a r b o u r, Mity. Modele. Paradygmaty. Studium porównawcze nauk przyrodniczych i religii, tłum. M. K ro ś n i a k, Kraków 1984, s. 15. 
życia prawdziwego, poza Prawdziwym Światłem. Prawdziwe Światło ofiaruje nam, ludziom, perspektywę życia wiecznego. Światło i życie w Bogu są tym samym, a tylko umysłem ujmujemy je w rożnych aspektach. Słusznie pisze Peter Henrici, że „historia grzechu rozpoczyna się od kłamstwa. Wąż kusiciel w raju przekręca słowa Boże. Zamiast jednego drzewa, z którego nie wolno było jeść Ewie, wymienia wszystkie drzewa; zamiast o grożącej niechybnej śmierci, mówi o śmierci natychmiastowej. Subtelna gra słów między nagością a mądrością, łącznie z podwójnym znaczeniem dobra i zła, podkreśla jeszcze bardziej dwulicowość sytuacji. Na drugim krańcu tej historii, z odnowionego nowego stworzenia, zostaną wykluczeni ci wszyscy, którzy kochają kłamstwo i nim żyją (Ap 21, 8; 22, 15). ${ }^{45} \mathrm{Ci}$, którzy ulegają ciemnościom kłamstwa tracą również życie. Taka sytuacja to ostateczna klęska człowieka. Niestety, choć „Światło przyszło na świat, to jednak ludzie bardziej umiłowali ciemność" (por. J, 3, 19) ze smutkiem pisze św. Jan.

Człowiek zatem, ażeby zachować relację jednoczącą go z Bogiem, musi być istotą, która poznała i przyjęła Prawdę; Prawdę, która sama będąc czystą, czystą Prawdą, sprawia czystość tego, kto ją w wierze przyjmuje. Prawda, przychodzącego i udzielającego się człowiekowi Boga, oczyszcza. Ten, jakże ważny, temat oczyszczenia wielokrotnie podejmował papież Benedykt XVI. Według niego człowiek, ażeby wejść we wspólnotę, w komunię z Bogiem, musi być czysty. „Im bardziej zbliża się do światła, tym bardziej odczuwa, że jest brudny i potrzebuje oczyszczenia". ${ }^{46}$ Czystości tej jednak nie wypracowuje człowiek. Jest ona darem Bożym, na który człowiek nie zasługuje; może się tylko na jej przyjęcie otworzyć, albo zamknąć i ją odrzucić.

Pan Jezus jeszcze przed swoją męką mówił do apostołów: „I wy jesteście czyści” i dodał ,ale nie wszyscy. Wiedział bowiem, kto Go wyda, dlatego powiedział: Nie wszyscy jesteście czyści..." (J 13, 10-11).

45 P. H e n r i c i, Grzech jako nieprawda. (Próba filozoficznego zbliżenia), tłum.

L. B a 1 t e r, Communio 55(1990) nr 1, s. 22.

46 J. R a t z ing e r/ B e n e d y k t XVI, Jezus z Nazaretu, cz. 2, s. 69. 
„Dar czystości jest dziełem Boga... - pisze Benedykt XVI. - Zstępujący do nas Bóg czyni nas czystymi. Czystość jest darem". ${ }^{47}$

Taką myśl niosą w sobie słowa św. Piotra, który zwolennikom zobowiązania nowo nawróconych chrześcijan do przestrzegania Prawa Mojżeszowego odpowiada, że to sam Bóg postanowił, ,żeby poganie usłyszeli słowa Ewangelii i uwierzyli. (...) Nie zrobił żadnej różnicy pomiędzy nimi a nam - kontynuował apostoł - oczyszczając ich serca przez wiarę" (Dz 15, 5-11) Benedykt XVI opatruje przytoczony tekst krótkim komentarzem: „Serce oczyszcza wiara. Jest ona darem Boga dla człowieka". ${ }^{48}$

Papież Benedykt XVI poświęca wiele uwagi właśnie problematyce oczyszczenia. „Ten wielki temat oczyszczenia - pisze on - zaledwie dotknięty w mowie Piotra, został na nowo podjęty i pogłębiony przez Jana w opisie umycia nóg, i w kluczowym słowie «uświęcenie», w arcykapłańskiej modlitwie Jezusa. «Wy już jesteście czyści dzięki słowu, które wypowiedziałem do was», zapewnia Jezus swych uczniów w mowie o winnym krzewie $(15,3)$. Jego słowo przenika do ich wnętrza, przemienia ich myśl i wolę, ich «serce» i tak je otwiera, że staje się sercem widzącym". ${ }^{49}$

Papież przywołuje także arcykapłańską modlitwę Jezusa, który modli się do Ojca, prosząc ,uświęć ich w prawdzie" (J 17, 17). Uświęcić - wyjaśnia Benedykt XVI - znaczy najpierw, stać się zdolnym do sprawowania kultu, czyli czynności rytualnych, jakie musiał dokonać kapłan zanim stanął przed Bogiem. Wejście w prawdę staje się przeto „kąpielą" otwierającą człowieka na Boga. Ażeby wyzbyć się brudu, który oddziela człowieka od Boga, człowiek musi się w niej, to znaczy w prawdzie, cały zanurzyć. Trzeba pamiętać, że Jan nie pisze o prawdzie, jako o „czymś”, ale o prawdzie ujętej w najgłębszym i ostatecznym znaczeniu, czyli o „kimś”, o Jezusie, który jest Prawdą. Do tej kąpieli oczyszczającej człowieka czyni zdolnym jedynie miłość

\footnotetext{
47 Tami̇e, s. 76.

48 Tamże, s. 70.

49 Tamże, s. 70-71.
} 
Jezusa posuwająca się aż do oddania życia. ${ }^{50}$ „Słowo Jezusa jest nie tylko słowem, ale Nim samym. A Jego słowo jest prawdą i miłością". ${ }^{51}$

Konkludując, możemy powiedzieć, że na zaznaczoną w tytule artykułu problematykę można spojrzeć w dwojaki sposób. Pierwszy z nich realizuje się przez eksplorację faktów, które złożyły się na ekonomię zbawienia człowieka. Drugi sposób jest hipotetyczny, wskazujący na możliwą drogę zbawienia człowieka, która sama w sobie jest niesprzeczna, natomiast zabrakło dostatecznych racji (zabrakło ich - jak utrzymuje ta hipoteza - przez złość człowieka i odrzucenie orędzia królestwa Bożego głoszonego przez Jezusa) do jej urzeczywistnienia.

Co wnosi owa hipoteza i czy warto się nią zajmować? Czy nie jest to czysta, mało znacząca akademicka dysputa? Wydaje się, że rozważanie tych tajemnic ma kapitalne znaczenie i to większe nawet - co zaznaczyliśmy we wstępie - dla relacji człowieka z Bogiem niż dla teologii jako nauki.

Waga treści zawartych w zaprezentowanej tu hipotezie jest istotna dla antropologii rozumianej integralnie, czyli antropologii filozoficznej i teologicznej, oraz filozofii i teologii dialogu. Wydaje się bowiem, że pokazuje ona bardziej wyraziście miłość Boga ku człowiekowi, a tym samym domaga się, jak każda miłość, odpowiedzi wzajemności. W tym swoistym, procesualnym, ukazaniu przebiegu ekonomii zbawienia widać, jak Bóg umiłował człowieka i jak postanowił pojednać go ze sobą za wszelką cenę. Chciał zapłacić „cenę wystarczającą”, przez głoszenie i ofiarowanie, odwróconemu od Niego człowiekowi, królestwa Bożego. Człowiek jednak nie chciał wejść na drogę nawrócenia i przyjęcia Słowa Bożego - Słowa Światła i Życia. Bóg jednak tak umiłował człowieka, że nie zrezygnował z jego zbawienia i zapłacił za niego cenę nad cenami, cenę, nad którą już nic nie ma, cenę najokrutniejszej męki krzyżowej i śmierci swojego Syna. W tym spojrzeniu zatem, Kalwaria nie byłaby postanowieniem Boga, ale Jego gotowością. Przez swoją niewiarę, przez swoją zatwardziałość,

\footnotetext{
50 Tamże, s. 71.

51 Tamże.
} 
przez umiłowanie grzechu i ciemności, człowiek wyznaczył Bogu cenę swojego odkupienia. Wyrok wykonany w czasie biczowania, cierniem ukoronowania zakończony ukrzyżowaniem - to dzieło człowieka. Przy czym, zwracając się ku owemu możliwemu rozwiązaniu, w celu pełniejszego jego zrozumienia, nie trzeba chcieć zamknąć go jedynie w perspektywie czasu liniowego. Jezus z Nazaretu żył przecież w czasie liniowym, ale zmian w decyzjach Słowa Ojca czasem liniowym nie wytłumaczymy. Jeżeli umysł ludzki chciałby głębiej w nie wniknąć, być może sensowne byłoby odwołanie się do np. filozofii procesu według myśli A. N. Whiteheada i Ch. Hartshorne'a. Najważniejsze jednakże jest nieustanne zachowanie pamięci, że stoimy wobec Tajemnicy miłości Bożej, której bardziej jesteśmy należni wdzięczność i kontemplację, niż jasne jej umysłowe uchwycenie.

Czy w sytuacji, gdyby człowiek przyjął orędzie Mesjasza i nie doszłoby do ukrzyżowania, czy to nie umniejszyłoby Jego miłości ku człowiekowi? Absolutnie nie. Przecież już samo wcielenie - przyjęcie ludzkiej natury przez Drugą Osobę Bożą - było wystarczającym uniżeniem się Boga, który dokonał tego, aby przynieść ludziom zbawiającą Dobrą Nowinę. Gdyby nie było męki i śmierci krzyżowej nic by nie zostało umniejszone z miłości Boga ku człowiekowi. Możemy tutaj posłużyć się analogią. Tak jak dziecko, za które matka nie musiała oddać swojego życia, wcale nie czuje się mniej kochane od tego, za którego taki wyraz miłości musiał się dokonać. Przeciwnie, dziecko, dla którego ocalenia matka musiała ponieść śmierć, żałuje, że tak się stało, że aż takiej ceny wymagał jego ratunek.

Zresztą, czyż nie taka jest sukcesja postępowania tych, którzy najdoskonalej idą śladami Chrystusa, czyli męczenników? Naśladując swojego Mistrza, idą głosić Jego Ewangelię. Ich celem nie jest przecież pozbawienie siebie życia, ale głoszenie dającej życie Dobrej Nowiny. Kiedy jednak ich nauka zostaje odrzucona, gdy sami są prześladowani, to nie wahają się złożyć ofiary ze swojego życia. Niemalże spontanicznie nasuwa się tutaj schemat zapisany przez Karola Wojtyłę w poemacie Stanisław. Męczennik ze Skałki, chcąc nawrócić króla Bolesława Śmiałego, według słów poety, tak myślał: 
„Myślał może Stanisław: słowo moje zaboli ciebie i nawróci,

Przyjdziesz do bram katedry jak pokutnik,

Przyjdziesz postem wycieńczony, prześwietlony wewnętrznym głosem...

I dołączysz się do Stołu Pańskiego jak marnotrawny syn.

Słowo nie nawróciło, nawróci krew". 52

Zawsze taki sam schemat: najpierw słowo, a jeżeli potrzeba, to potem także i krew.

Trzeba też wreszcie dodać, że wszelkie ludzkie spekulacje, jak długo nie mogą odwołać się do Nauczycielskiego Urzędu Kościoła, pozostają tylko ludzkim wysiłkiem przeniknięcia największych Tajemnic, muszą zatem dokonywać się w postawie pokornej, z zachowaniem w żywej pamięci słów, które Bóg wypowiedział do człowieka przez proroka Izajasza: „Myśli moje nie są myślami waszymi ani wasze drogi moimi drogami - mówi Pan. Bo jak niebiosa górują nad ziemią, tak drogi moje nad waszymi drogami i myśli moje nad myślami waszymi” (Iz 55, 8-9).

Rafat K. WILK OSPPE

Słowa kluczowe: Odkupienie, usprawiedliwienie, proroctwa, głoszenie, męka, krzyż, prawda

Keywords: Redemption, justification, prophecy, proclamation, Passion, Cross, truth

52 K. Woj t yła, Poezje i dramaty, Kraków 1979, s. 105 


\section{Whether the Redemption must have been accomplished through the Passion and Death on a Cross of Jesus Christ}

\section{Summary}

The author raises the question of whether the redemption of man must have been accomplished through the Passion and Death on a cross of Jesus Christ, or whether it could have been realized by the people's acceptance of the message of the Gospel. By analyzing the historical aspect, such as understanding the prophecies by the Jews and especially by the Apostles, it seems that the latter was possible. It was only after the rejection of the proclaimed Kingdom of God that the Son of God paid the greatest price and that is by giving up his life for the redemption of mankind. Romano Guardini favors this solution. The author of the study also shows reasons for opposing opinions which are more deeply rooted in the tradition of preaching. Belonging to this group are, among others, Pope Benedict XVI, who writes that it is not contradictory to maintain that Jesus wanted to reconcile the people with the Father only by accepting the Kingdom proclaimed to them. However, when the people rejected the Gospel which was proclaimed by the One who loved them, he accepted this rejection as well as all its extreme consequences, namely the Passion and Death on a cross. Nevertheless, the Pope writes that this version cannot be proven in any way by referring to the Gospel records. Since there are no sufficient sources of evidence, other schemes of the salvation of humanity apart from the Passion and Death on a cross can only be a hypothesis. Hence, they are just a result of pure speculation, and as such are outlined in this study. 